Włodzimierz Tyburski

Akademia Pedagogiki Specjalnej

im. Marii Grzegorzewskiej, Warszawa

e-mail: Wlodzimierz.Tyburski@umk.pl

\title{
Myśl humanistyczna na rzecz ochrony środowiska przyrodniczego
}

DOI: http://dx.doi.org/10.12775/RF.2017.003

Nie trzeba chyba już dziś nikogo przekonywać, że sytuacja ekologiczna świata w wymiarze globalnym jest trudna, w niektórych zaś jego lokalnych rejonach wręcz dramatyczna. Każdy zainteresowany tematyką może bez trudu sięgnąć do licznych publikacji, także do obszernych, pisanych przez liczne autorytatywne grona specjalistów ekspertyz i raportów o stanie świata (np. Word Wide Fund for Nature - WWF), aby pozyskać informacje o zasięgu, charakterze i tempie niekorzystnych zmian. Zdecydowanie wybrzmiewa tam nawoływanie do zaprzestania dalszego „podkopywania fundamentów piramidy życia” na naszej planecie. Zmiany klimatyczne, degradacja wód, gleby i powietrza, wymieranie gatunków flory i fauny, dramatyczne kurczenie się powierzchni lasów, topnienie lodowców - oto kilka przykładów zaświadczających o dokonującej się w naszych czasach destrukcji świata przyrody i warunków życia człowieka. Zresztą o tym, że procesy degradacyjne nasilają się W szybkim tempie, a "zdrowie" naszej planety pogarsza się w stopniu niemającym dotąd precedensu, przekonujemy się nieomal naocznie, obserwując kataklizmy (niektórzy doświadczając ich dramatycznych skutków), które niedawno, nawiedziły różne rejony planety. Najbardziej spektakularnym - jeśli tak można rzec - przejawem owych procesów są zmiany klimatu i ich dramatyczne następstwa. Mogliśmy się o tym dotkliwie przekonać, doświadczając skutków huraganu o niespotykanym dotąd nasileniu, który w lecie tego roku nawiedził nasz kraj (zwłaszcza województwo pomorskie i kujawsko-pomorskie). Z jego negatywnymi konsekwencjami borykać się będzie przyroda, a wraz z nią 
mieszkańcy tych terenów, jeszcze przez długi czas. W skali nieporównanie większej prawdziwą hekatombą był huragan Irma, pustoszący Karaiby i Florydę oraz huragan Maria, który zdewastował m.in. wyspy karaibskie, Dominikanę, Portoryko. Są to huragany o najwyższym natężeniu, osiągającym pięciostopniową kategorię. Przy czym zwiększa się ich liczba i nasilenie oraz rozmiary różnego rodzaju katastrof nimi spowodowanych. Kolejne nawałnice nadal pustoszą wspomniane regiony. Dominuje dziś pogląd, że za obecne zmiany klimatyczne odpowiadają w głównej mierze czynniki antropogenne, to jest pozbawiona poczucia odpowiedzialności, szkodliwa dla środowiska przyrodniczego działalność człowieka. Dlatego poważne ekspertyzy i raporty naukowe analizujące tę sytuację biją na alarm, wskazując na potrzebę radykalnych działań zapobiegających szybko postępującej degradacji klimatu, gdyż nie ulega wątpliwości, że adaptacja do zmieniających się warunków klimatycznych będzie w niedalekiej przyszłości wielokrotnie droższa niż działania na rzecz ochrony klimatu. Ten sposób myślenia, dyktowany prostym rachunkiem powinien mam towarzyszyć, gdyż bez niego międzynarodowa i krajowa polityka klimatyczna nie może być prowadzona w sposób rozsądny i zrównoważony. Klimat można ochronić skutecznie tylko w warunkach międzynarodowej solidarności, poczucia odpowiedzialności i współpracy krajów rozwiniętych i rozwijających się, ale tylko wtedy, gdy wzniosą się ponad własny, wąski interes i zaczną myśleć i działać w kategoriach solidarności klimatycznej. Należy zatem oczekiwać od polityków (także polskich) rezygnacji ze źle pojmowanego izolacjonizmu i zastąpienia go polityką wynikającą z potrzeby działania w imię globalnej odpowiedzialności i solidarności klimatycznej.

Zmiany klimatyczne wybijają się, zwłaszcza na skutek ostatnich wypadków, na pierwszy plan w katalogu zjawisk i procesów zagrażających środowisku przyrodniczemu. Wiemy, że skuteczne przeciwstawianie się im wymaga różnorodnych działań o charakterze inżyniersko-technicznym, zmian w technologii produkcji, aktywnego wysiłku wielu dyscyplin naukowych (przyrodniczych, ekonomicznych, prawnych), jak również organizatorów życia społecznego i gospodarczego, a przede wszystkim ludzi i instytucji reprezentujących różne dziedziny oraz zainteresowania, ale zjednoczonych wspólną ideą walki o powstrzymanie degradacji środowiska przyrodniczego człowieka.

Nie zawsze dostatecznie zdajemy sobie sprawę z tego, że w tej wielkiej misji, której zadaniem jest powstrzymanie choroby drążącej świat, ważną rolę do odegrania mają nauki humanistyczne. $\mathrm{Z}$ jednej strony dają one szerszą i pogłębioną analizę świadomościowo-kulturowych przyczyn i uwarunkowań kryzysu ekologicznego, z drugiej dysponują dużymi możliwościami w zakresie kształtowania świadomości, pobudzania motywacji, kreowania postaw i zachowań proekologicznych. Spełniają także istotną funkcję $\mathrm{w}$ dostarczaniu tak potrzebnych uzasad- 
nień dla działań przyjaznych środowisku. Innymi słowy - dyscypliny humanistyczne, korzystając z wyników własnych dociekań oraz z wiedzy o stanie środowiska dostarczanej przez nauki przyrodnicze, powinny i są w stanie wypracować nowy model relacji pomiędzy człowiekiem, kulturą a przyrodą. A to oznacza, że rzetelna wiedza humanistyczna może posłużyć (i czyni to z powodzeniem) w wytyczeniu norm, dyrektyw i wskazań określających i regulujących nasze konkretne odnoszenie się do przyrodniczego otoczenia. Stawia więc przed sobą także wyraźne cele praktyczne.

Z perspektywy dyscyplin humanistycznych zorientowanych na problematykę ochrony środowiska dokonywane są również oceny i wartościowania naszych postaw i zachowań wobec przyrodniczego otoczenia o charakterze etycznym, estetycznym, psychologicznym, wychowawczym, a nawet religijnym. Potrzebę ujawnienia licznych związków humanistyki z ekologią uzasadnia słuszne przekonanie, że zachowanie się człowieka wobec przyrody (korzystne lub szkodliwe dla niej) w znacznym stopniu zależy od poziomu jego świadomości, wyznawanego systemu wartości, wzorów kulturowych, wrażliwości, charakteru wychowania itp. Jeśli tak rzeczywiście jest - $\mathrm{w}$ co nie wątpimy - to nie można skutecznie chronić środowiska, ignorując znaczenie świata wartości, zasad, norm czy wychowania moralnego, gdyż określone zapatrywania filozoficzne, etyczne, estetyczne czy religijne mogą w istotny sposób motywować, pobudzać i wzmacniać poczynania odnoszące się do praktycznych kontaktów człowieka z przyrodniczym otoczeniem. Ten fakt bardzo trafnie spuentowała Kenneth White w stwierdzeniu, że „ekologia jest sprawą głęboko kulturową". Dlatego ochrona środowiska powtórzmy to jeszcze raz - nie może sprowadzać się do określonych działań organizatorskich, ekonomiczno-prawnych i techniczno-technologicznych. To nazbyt wąskie jej rozumienie. Ważne jest to, jakie przekonania, wzory kulturowe zachowań, wartości i idee generują całokształt naszych odniesień do świata przyrody. Nie ulega wątpliwości, że przy takim wyjaśnianiu relacji człowiek-przyroda właśnie dyscypliny humanistyczne mają do odegrania pierwszoplanową rolę. Ponadto to właśnie te dyscypliny moga nam pomóc w uzyskaniu odpowiedzi na pytanie o przyczyny kryzysu ekologicznego, ponieważ dysponują takim potencjałem wiedzy, dzięki któremu są w stanie podjąć (i to czynią) gruntowne studia ujawniające kulturowe, świadomościowe i cywilizacyjne determinanty dokonujących się $\mathrm{w}$ środowisku przyrodniczym procesów kryzysowych.

Takie między innymi oczekiwania formułowane przed współczesną refleksją humanistyczną ukierunkowaną na szeroko rozumianą problematykę ekologiczną przyczyniły się do wypracowania tzw. humanistycznego kierunku ochrony środowiska, określanego także mianem humanizmu ekologicznego. Jego konkretyzacją są wyodrębnione 
w ostatnich dziesięcioleciach takie dyscypliny badawcze, jak: ekofilozofia, etyka środowiskowa czy ekopedagogika, które wraz z innymi dyscyplinami humanistycznymi zaangażowanymi na rzecz ochrony środowiska: ekoestetyka, psychologią ekologiczną czy ekoteologią uzupełniają nauki przyrodnicze, techniczne i prawne, zaangażowane na rzecz ochrony środowiska o wymiar filozoficzny, aksjologiczny (etyczny i estetyczny) oraz edukacyjno-wychowawczy. Dyscypliny te, odwołując się do świata wartości, podejmują wysiłek dostarczania jasnych i przekonujących argumentów na rzecz przeciwstawiania się dalszej instrumentalizacji zachowań ludzkich wobec przyrody oraz kształtowania postaw przyjaznych środowisku. W konsekwencji łączą refleksję teoretyczną z wyraźnie zaakcentowanymi ambicjami praktycznymi. Przedstawmy zatem, tu zaledwie w wymiarze anonsującym, wymienione wyżej dyscypliny zaangażowane na rzecz ochrony środowiska przyrodniczego ${ }^{1}$.

\section{Filozofia środowiskowa (ekofilozofia)}

Filozofia środowiskowa (ekofilozofia) jest próbą przemyślenia na nowo i określenia miejsca człowieka w uniwersum. Z jednej strony (retrospektywnej) dąży do ukazania tego zespołu uwarunkowań filozoficznych, kulturowych i światopoglądowych, które w dobie nowożytnej generowały myślenie skrajnie utylitarne, pozytywistyczno-technokratyczne, a którego praktyczne konsekwencje okazywały się tak bardzo niebezpieczne dla przyrodniczej rzeczywistości, z drugiej (prospektywnej) wnosi swój znaczący potencjał w dzieło budowania nowego myślenia o człowieku i świecie przyrody, uświadamia potrzebę lepszego zrozumienia wspólnoty losów człowieka i świata przyrody, włącza się aktywnie w działania mające na celu projektowanie wizji przyszłości, budowanie modelu cywilizacji zorientowanej na potrzeby ekologiczne. Najlepiej zaświadcza o tym niekwestionowany wkład ekofilozofii w konstruowanie podstaw najpierw idei ekorozwoju, a obecnie zrównoważonego rozwoju. Innymi słowy przypomina ona, że taki rozwój, który podcina warunki egzystencji biologicznej człowieka poprzez to, że niszczy jego środowisko przyrodnicze, jest $\mathrm{w}$ istocie regresem nawet wtedy, gdy umożliwia powiększenie dóbr materialnych i konsumpcyjnych. Zdecydowanie zaś opowiada się za taką koncepcją rozwoju, która doskonali społeczne i ekonomiczne warunki życia człowieka, nie degradując jego przyrodniczego otoczenia. Nie sposób w związku z powyższym nie zauważyć, że

1 Bardziej obszerną prezentację wyżej wymienionych dziedzin humanistycznych ukierunkowanych na problematykę ochrony środowiska przyrodniczego przedstawiłem w książce pt. Dyscypliny humanistyczne i ekologia, Wydawnictwo Naukowe UMK, Toruń 2013. 
filozofia środowiskowa wprowadza w myślenie człowieka o przyrodniczym otoczeniu nowe idee, oparte na regule przyjaznych relacji, gdzie przyroda jawi się nie tyle jako przeciwnik lub obiekt eksploatacji, ile jako partner człowieka w wspólnej odysei życia. Zapewne mottem tego przeświadczenia mogłaby być myśl, którą H. G. Gadamer sformułował następująco: „na przyrodę nie można już więcej patrzeć jak na przedmiot wykorzystania, musi ona we wszystkich formach jej jawienia się być doświadczana jako partner" 2 .

W świetle zaanonsowanych tu, w dużym skrócie, wypowiedzi warto zauważyć, że pytanie o stosunek człowieka do przyrody jest $\mathrm{w}$ istocie pytaniem o nową filozofię rozwoju i życia, a więc o taki kierunek przeobrażeń, który uwzględnia zarówno potrzeby człowieka, jak i interesy pozaludzkich istot żywych - całej przyrody, w konsekwencji jest pytaniem o taki model cywilizacji, która byłaby - chyba po raz pierwszy w harmonii z przyrodą. Czy uda się taki model wypracować? Wydaje się, że przynajmniej w sferze koncepcyjnej jesteśmy na dobrej drodze, ale zdołamy nadać mu realną postać i konsekwentnie wprowadzać w życie i praktykę działania? Na to drugie pytanie trudno dziś sformułować jednoznacznie brzmiącą odpowiedź - nie wiadomo. Mimo wielu trudności i przeszkód należy podejmować wysiłki i konsekwentne, zdeterminowane działania, aby owa odpowiedź przybrała pozytywny sens.

\section{Etyka środowiskowa (ekoetyka)}

Etyka środowiskowa, podobnie jak ekofilozofia, wyrosła z troski o stan świata przyrody; koncentruje swe zainteresowania na ujawnianiu moralnych relacji między człowiekiem, społeczeństwem a środowiskiem przyrodniczym. Nie tylko analizuje te relacje w kategoriach moralnych, lecz także nadaje im status moralny. Tym samym, w przeciwieństwie do tradycyjnej etyki, poszerza zakres moralności, wykraczając poza świat relacji interpersonalnych i obejmując nią świat pozaludzki. Stawia sobie za zadanie obronę środowiska przyrodniczego przed ludzkimi działaniami destrukcyjnymi oraz obronę człowieka jako jednostki i gatunku przed negatywnymi skutkami jego agresywnej aktywności w środowisku. Wypracowując i uzasadniając aksjologiczne oraz deontologiczne programy określające relacje człowieka ze środowiskiem, wzbogacają niepomiernie wszelkie próby odpowiedzi na zasadnicze pytanie: jak powinien zachować się człowiek wobec swego przyrodniczego otoczenia i dlaczego powinien tak postępować? $\mathrm{W}$ tym celu pragną one wypracować model aksjologicznych preferencji w relacjach człowieka z przyrodą, tak by wartości moralne stanowiły ważne kryterium regulujące

\footnotetext{
2 H. G. Gadamer, Dziedzictwo Europy, Wyd. Spacja, Warszawa 1992, s. 20.
} 
owe relacje. Wiemy, że wartości te mogą wydatnie wpływać na tonowanie możliwych konfliktów między działającym człowiekiem a przyrodą oraz umożliwiają dokonywanie takich wyborów, które sprzyjają zachowaniu równowagi ekologicznej w sytuacji, gdy człowiek ingerując w świat przyrody, przystosowuje ją do swych potrzeb. Etyka środowiskowa koncentruje swe zainteresowania przede wszystkim na tych wartościach, które sprzyjają zachowaniu życia oraz równowagi i harmonii ekosystemów. Przy czym mocno akcentowany jest tu związek refleksji teoretycznej z oczekiwaniami o charakterze praktycznym. Zadaniem teorii jest zbudowanie i uzasadnienie określonego systemu wartości i norm określających właściwe relacje człowieka ze światem przyrody, który następnie edukacja ekologiczna pragnie wpisać w sferę świadomości indywidualnej i społecznej, dążąc w konsekwencji do kształtowania takich postaw i zachowań, które wywierałyby korzystny wpływ na całokształt praktycznych stosunków człowieka z przyrodniczym otoczeniem. Trudna i skomplikowana problematyka ochrony środowiska jest więc dla tej etyki szczególnym wyzwaniem, którego probierzem jest wzięcie odpowiedzialności za losy i dobro świata przyrodniczego, w którym żyjemy i z którym pragniemy harmonijnie współżyć.

\section{Ekoestetyka (Ekologiczna estetyka przyrody)}

Przedmiot zainteresowań tej dyscypliny (trafnie go identyfikuje jej tytuł) lokuje się na styku estetyki i ekologii. Jest współczesną dziedziną wiedzy, ale nawiązuje do tych tradycji i nurtów w estetyce, dla których świat natury był przedmiotem twórczych inspiracji i zainteresowań. Łączy ambicje teoretyczne $\mathrm{z}$ wymogami natury praktycznej. W pierwszym wymiarze pragnie poznać zjawiska związane z pięknem natury i, jak powiada M. Gołaszewska, rozeznać „w jakim stopniu piękno rzeczywistości, natury przyrody przyczynia się do powstawania specyficznej postawy estetycznej wypływającej z wrażliwości człowieka na piękno natury"'3. Gdy zaś ekoestetyka stawia przed sobą zadania o charakterze praktycznym, to przede wszystkim zmierza do rozpoznania „,działania mechanizmów wpływu przeżyć estetycznych na formowanie postawy proekologicznej”" i czyni to, żywiąc przekonanie o znaczącej, proekologicznej roli piękna natury. $Z$ perspektywy ochrony przyrody ważne jest, aby żywe reakcje na środowisko wyrażały się w postawach i zachowaniach na rzecz obrony tego środowiska przed różnymi działaniami szkodliwymi i dewastującymi. Natomiast z perspektywy estetyki

3 M. Gołaszewska, Ogólnoteoretyczne założenia ekoestetyki. Okoliczności badań estetyki ekologii, w: Poznanie i doznanie. Eseje z estetyki ekologii, Kraków 2000, s. 14.

4 Ibidem, s. 14-15. 
istotne znaczenie ma to, aby zainteresowanie środowiskiem wyrażane było w ochronie jego piękna i bogactwa walorów estetycznych. Dlatego ważne jest rozwijanie wrażliwości estetycznej na piękno natury jako czynnika wydatnie wzmacniającego postawę proekologiczną. Idzie tu także o budowanie tego, co można by nazwać satysfakcją estetyczna, która wzmaga potrzebę bliskich kontaktów z naturą. To także istotne zadanie, które formułowane jest przed przeżywającą swój dynamiczny rozwój sztuką ekologiczną. Kreowane przez nią dzieła artystyczne są inspirowane zjawiskami świata natury i pragną przekazać jaką́ prawdę o związkach człowieka z przyroda, o ewolucji naszych postaw wobec świata przyrody, jej piękna, lepiej i wyraziściej uświadamiają prawa, ale i krzywdy przyrody. Ten rodzaj sztuki umożliwia nam nawiązanie swoistego dialogu z przyrodą i w jego efekcie odkrywania jej estetycznej wartości.

\section{Psychologia ekologiczna}

Z kolei psychologia ekologiczna skupia uwagę na psychologicznym wymiarze relacji człowiek-przyroda, interesując się tym, jak w tej perspektywie ludzie wpływają na środowisko oraz jak ono wpływa na ludzi. Zorientowana na problematykę przyrodniczą refleksja psychologiczna dostarcza wiedzy przypominającej z jednej strony o pozytywnym, terapeutycznym wpływie natury na nasze zdrowie i życie, z drugiej o tym, że człowiek, niszcząc swoje przyrodnicze otoczenie, pozbawia się niezwykle korzystnych wpływów, jakie na stan naszego zdrowia, zarówno w jego wymiarze fizycznym, jak i psychicznym, wywiera środowisko przyrodnicze. W świetle badań nie ulega wątpliwości, że zniszczone środowisko negatywnie wpływa na fizyczną kondycję człowieka, znacznie obniża jakość życia, powoduje destrukcyjne zmiany w psychice ludzkiej. Psychologia ekologiczna analizuje nasze reakcje na sytuacje kryzysowe, pokazuje różne formy dostosowania się do wymogów środowiska, ale także adaptacji ludzi do zagrożeń. Śledzi i analizuje ich dynamikę. „Jeśli człowiek ma przeżyć kryzys ekologiczny - pisał swego czasu Robert Disch - może zrobić to tylko przez rozwój ekologicznej psychiki (ecological psyche), która pozwala mu wybudować most nad tym, o czym myślał, że jest naturalne, oraz rozpoznanie, że jest on nie tylko w jakiś sposób powiązany z natura, ale że jest naturą" ${ }^{\prime \prime}$.

Występuje z postulatem kreowania takich warunków środowiskowych, aby każdy członek społeczności miał możliwość rozwoju oraz ochrony zdrowia psychicznego. Z kolei psychologia krajobrazu - wyspecjalizowana dziedzina psychologii ekologicznej - potwierdza, że

\footnotetext{
5 R. Disch, The ecological conscience. Values for survival, New Jersey 1970.
} 
kształtowanie percepcji i rozwijanie wyobraźni w kontakcie z krajobrazem ma istotne znaczenie dla naszych funkcji psychicznych. Przede wszystkim wpływa na poziom afektywnego powiązania człowieka ze środowiskiem przyrodniczym, przeżywania więzi podmiotu z jego naturalnym otoczeniem, z jego zwierzęcymi, roślinnymi i krajobrazowymi komponentami. Jest to oczywiście funkcją naszego uwrażliwienia na wartości krajobrazu, co przekłada się na obywatelską odpowiedzialność za jakość otoczenia, panujący w nim ład i kulturę przestrzeni. Psychologia ekologiczna analizuje wpływy środowiskowe, ale także dowodzi, że ważnym komponentem dobrego, zdrowego, przynoszącego równowagę, pogodę i radość życia są udane, dobre relacje człowieka z jego przyrodniczym otoczeniem.

\section{Ekoteologia}

Dyscyplina ta pojawiła się jako wyraz troski i zaniepokojenia kościołów chrześcijańskich pogarszającą się sytuacją ekologiczną świata i stawia przed sobą dwa podstawowe zadania: a) przemyślenia problemu ochrony środowiska z pozycji teologicznego przesłania i teologicznych konsekwencji; b) potrzeby sformułowania chrześcijańskiej odpowiedzi na kryzys ekologiczny. Powstała i rozwija się jako dzieło wspólnotowego działania i zaangażowania kościołów i jednocześnie jest świadectwem jednoczenia się chrześcijan wokół fundamentalnego zadania, jakim jest ochrona środowiska oraz trudnych wyzwań, jakie są z nim związane. Potrzebę solidarnych, wspólnotowych wysiłków mających na celu zapobieżenie narastającym zagrożeniom świata przyrody i człowieka akcentuje Kościół katolicki, kościoły protestanckie i prawosławne. I choć dają się zauważyć nieco odmienne podejścia poszczególnych kościołów do problematyki ekologicznej, a może raczej różne rozkładanie akcentów w poszczególnych kwestiach, to jednocześnie wyraźnie ujawnia się wspólnotowy rdzeń dla formułowanych myśli, poglądów i przekonań. Kościoły łączy akcentowanie zagrożeń niesionych przez współczesny, zorientowany technokratycznie rozwój cywilizacyjny, który generuje niesprawiedliwy podział dóbr materialnych i traktuje wzrost gospodarczy jako dobro o najwyższej randze. Wspólnie podkreśla się, że naruszona została hierarchia wartości, czego przejawem jest waloryzacja świata rzeczy, wzrost nastawień i postaw konsumpcyjnych, wyraźny w naszych czasach proces nasilania się tych zjawisk. Wyrażane są także obawy związane z gwałtownym przyspieszeniem technologiczno-przemysłowym w kontekście jego negatywnego wpływu na stan równowagi świata przyrody. Podzielane jest także przekonanie, że motywacje religijne są dla ludzi liczącą się zachętą i ważnym bodźcem do podejmowania aktywnych działań na rzecz ochrony środowiska przyrodniczego, że 
głos Kościoła (kościołów) w sprawach środowiska jest nie tylko wysłuchiwany, lecz ma siłę mobilizującą wyznawców do aktywnych poczynań proekologicznych. Do katalogu tematów podejmowanych w refleksji ekoteologicznej kościołów należy zagadnienie teologii życia, teologii stworzenia (na nowo przemyślanej), ekosprawiedliwości, pokoju, prawa przyszłych pokoleń, etycznych i teologicznych aspektów zmian klimatu, i wiele innych ${ }^{6}$. Mocno eksponuje się przekonanie, że sytuacja ekologiczna świata staje się dziś poważnym "problemem sumienia i kultury", jak również wskazuje się na potrzebę podejmowania zintegrowanych działań resuscytacyjnych i edukacyjnych w duchu kultury proekologicznej. Ważnym, jeśli nie najważniejszym, dokumentem Kościoła katolickiego w sprawie ekologii jest encyklika papieża Franciszka „Laudato si”" oparta na solidnych podstawach naukowych.

\section{Ekopedagogika}

Szczególne doniosłe znaczenia praktyczne wiąże się z ekopedagogiką. Jej z kolei zadaniem jest budowanie świadomości, postaw i kultury ekologicznej w wymiarze indywidualnym i społecznym. Dziedzina ta zdąża do wypracowania strategii działań edukacyjnych nakierowanych na kształtowanie nowego myślenia dotyczącego relacji człowiek-przyroda, etosu i wzorca życia indywidualnego i społecznego, pożądanych systemów wartości. Nie do zakwestionowana jest jej doniosła rola i możliwości, jakimi dysponuje w zakresie kształtowania postaw przyjaznych światu przyrody. Zwracają na ten fakt uwagę wszystkie oficjalne dokumenty dotyczące idei ekorozwoju i zrównoważonego rozwoju. Edukacji nadają znaczenie priorytetowe i umieszczają ją na pierwszym miejscu $\mathrm{w}$ realizacji polityki ekologicznej państwa. Wskazuje się na potrzebę wypracowania strategii działań edukacyjnych, nakierowanych na kształtowanie nowego myślenia dotyczącego relacji człowiek-przyroda, kształtowania proekologicznego etosu i wzorca życia indywidualnego i społecznego, proekologicznych systemów wartości. Podkreśla się, że proces kształcenia i wychowania proekologicznego powinien być wieloprofilowy, zintegrowany, nasycony myśleniem holistycznym. W zgodzie z tym dyrektywami postuluje się prowadzenie edukacji na wszystkich poziomach, korzystania z wszelkich sprawdzonych jej form, to jest kształcenia formalnego, nieformalnego, nieoficjalnego i akcydentalnego. Szczególnie mocno podkreśla się praktyczny wymiar owych działań, ponieważ najlepiej nawet opracowane programy pozostają w sferze teo-

6 J. M. Dołęga, Ekologia i ekofilozofia w teologii chrześcijańskiej, w: Wprowadzenie do filozoficznych problemów ekologii, red. A. Papuziński, Wydawnictwo Wyższej Szkoły Pedagogicznej, Bydgoszcz 1999. 
rii, jeśli propagowanym treściom nie uda się przeniknąć do świadomości zbiorowej, indywidualnych postaw i zachowań, gdy konstruowane $\mathrm{w}$ ich ramach systemy wartości i normy nie są akceptowane i realizowane przez konkretnych ludzi. Edukacja ekologiczna powinna być oparta na wiedzy przyrodniczej i dorobku wymienionych wyżej nauk ekohumanistycznych, a zwłaszcza powinna być zharmonizowana ze światem wartości, który jest swego rodzaju busolą wyznaczającą pożądane zachowania indywidualne i społeczne oraz, ogólniej mówiąc, kierunek rozwoju. Nie ulega wątpliwości, że edukacja ekologiczna nie tylko dostarcza tak potrzebnej wiedzy, jest również swego rodzaju narzędziem umożliwiającym właściwe zarządzanie i podejmowanie dobrze uzasadnionych decyzji, ale także rozwija krytyczne myślenie, wzmacnia zdolność oceny rzeczywistości, kształtuje postawy proekologiczne, mobilizuje do realizacji celowych, racjonalnych i korzystnych dla człowieka oraz przyrody działań. Trzy składowe edukacji - wiedza, wartości i umiejętności - dają w sumie rzeczowe podstawy skutecznych działań proekologicznych. Oczekiwanym efektem wszelkich możliwych inicjatyw i poczynań edukacyjnych jest uksztaltowanie świadomości i postaw jednostkowych i zbiorowych, bez których aktywna i skuteczna ochrona środowiska przyrodniczego nie jest możliwa?

Wskazując na rozległy kompleks zagadnień znajdujących się na styku humanistyki i ekologii, pragniemy uwypuklić fakt, że świat relacji człowieka z przyrodą ma głęboko filozoficzny, aksjologiczny, psychologiczny i wychowawczy wymiar, wymagający nie tylko teoretycznego namysłu, ale również odniesień aktywnie zachęcających i mobilizujących do określonych, praktycznych poczynań.

Bez udziału i wsparcia wiedzy humanistycznej nie sposób dziś odpowiedzieć na szereg doniosłych pytań i rozwiązywać wielu najbardziej kluczowych dla ochrony środowiska problemów. Dlatego dla nauk humanistycznych graniczna sytuacja, w jakiej znalazły się współczesny świat i cywilizacja, stanowi wielkie wyzwanie.

Pod adresem wiedzy humanistycznej formułowane są wezwania do tworzenia systemów wartości, hierarchii celów społecznych i indywidualnych stanowiących podstawę dla nowych modeli życia i reguł

7 P. Domeracki, W. Tyburski, Podstawy edukacji i kształtowania świadomości społecznej w duchu zrównoważonego rozwoju, w: Zasady kształtowania postaw sprzyjających wdrażaniu zrównoważonego rozwoju, red. W. Tyburski, Wydawnictwo Naukowe Uniwersytetu Mikołaja Kopernika, Toruń 2011, s. 233-277. Patrz także: W. Sztumski, Jak kształtować świadomość dla potrzeb ekologii i trwałego rozwoju, „Problemy Ekorozwoju”, vol. 6, 2011, nr 1. 
postępowania w środowisku przyrodniczym. Idzie tu zwłaszcza o wypracowanie nowej filozofii rozwoju, wzbogaconej o wnioski wynikające z negatywnych doświadczeń ostatniego zwłaszcza stulecia. Dlatego dyscypliny te, odwołując się do świata wartości, podejmują wysiłek dostarczenia jasnych i przekonujących argumentów na rzecz przeciwstawiania się dalszej instrumentalizacji postaw ludzkich wobec przyrody, kształtowania zachowań przyjaznych środowisku oraz uświadamiają potrzebę lepszego zrozumienia wspólnoty losów człowieka i świata przyrody. W takim też kontekście i w takim znaczeniu można zasadnie mówić o ich doniosłym znaczeniu i istotnej roli, jaką mają do odegrania humanistyczny kierunek ochrony środowiska przyrodniczego i konstytuujące go dyscypliny.

\section{Bibliografia}

Bell P. A., Greene Th. C., Fisher J. D., Baum A., Psychologia środowiskowa, Gdańskie Wydawnictwo Psychologiczne, Gdańsk 2004.

Birnbacher D., Odpowiedzialność za przyszłe pokolenia - zakres i granice, „Studia Ecologiae et Bioethicae", t. 7, 2009.

Bonenberg M., Człowiek i ziemia, Wydawnictwa Oddziału Polskiej Akademii Nauk, Seria Nauka dla Wszystkich, Kraków 1999.

Böhme G., Filozofia i estetyka przyrody w dobie kryzysu środowiska naturalnego, Oficyna Naukowa, Warszawa 1998.

Capra F., Punkt zwrotny. Nauka, społeczeństwo, nowa kultura, PIW, Warszawa 1987.

Ciążela H., Podmiotowość a problemy globalne. Relacja podmiotowości sprawczej i podmiotowości moralnej, w: Odpowiedzialność globalna i edukacja globalna. Wymiary teorii i praktyki, red. H. Ciążela, W. Tyburski, Wydawnictwo Akademii Pedagogiki Specjalnej, Warszawa 2012.

Dołęga J. M., Ekologia w filozofii i teologii chrześcijańskiej, w: Wprowadzenie do filozoficznych problemów ekologii, red. A. Papuziński, Wydawnictwo Wyższej Szkoły Pedagogicznej, Bydgoszcz 1999.

Domeracki P., Tyburski W., Podstawy edukacji i kształtowania świadomości spotecznej w duchu zrównoważonego rozwoju, w: Zasady kształtowania postaw sprzyjajacych wdrażaniu zrównoważonego rozwoju, red. W. Tyburski, Wydawnictwo Naukowe Uniwersytetu Mikołaja Kopernika, Torun 2011.

Domka L., Kryzys środowiska a edukacja dla ekorozwoju, Wydawnictwo Naukowe Uniwersytetu Adama Mickiewicza, Poznań 1996.

Gadamer H. G., Dziedzictwo Europy, przeł. A. Przyłębski, Fundacja Aletheia, Warszawa 1992.

Gołaszewska M., Święto wiosny. Estetyka - nauka o pięknie natury, Uniwesitas, Kraków 2000. 
Hull Z., Wprowadzenie do filozofii zrównoważonego rozwoju. /.../ Zasady sprzyjajace wdrażaniu zrównoważonego rozwoju, red. W. Tyburski, Wydawnictwo Uniwersytetu Mikołaja Kopernika, Toruń 2011.

Jonas H., Zasada odpowiedzialności. Etyka dla cywilizacji technologicznej, przeł. M. Klimowicz, Wydawnictwo Platan, Kraków 1999.

Papuziński A., Życie-nauka-ekologia. Prolegomena do kulturalistycznej filozofii ekologii. Wydawnictwo Wyższej Szkoły Pedagogicznej, Bydgoszcz 2003.

Peccei A., One Hundred Pages for the Future, Pergamon Press, New York 1981. Piątek Z., Ekofilozofia, Wydawnictwo Uniwersytetu Jagiellońskiego, Kraków 2008.

Skolimowski H., Filozofia żyjąca. Eko-filozofia jako drzewo życia, tłum. J. Wojciechowski, Wydawnictwo Pusty Obłok, Warszawa 1993.

Tyburski W., Etyka i ekologia, Polski Klub Ekologiczny, Torun 1995.

Tyburski W., Dyscypliny humanistyczne i ekologia, Wydawnictwo Naukowe Uniwersytetu Mikołaja Kopernika, Toruń 2013.

Wprowadzenie do filozoficznych problemów ekologii, red. A. Papuziński, Wydawnictwo Wyższej Szkoły Pedagogicznej, Bydgoszcz 1999.

\section{Streszczenie}

\section{Myśl humanistyczna na rzecz ochrony środowiska przyrodniczego}

W poczynaniach mających na celu powstrzymanie postępującej w niezwykle szybkim tempie degradacji środowiska przyrodniczego ważne zdania do spełnienia mają dyscypliny humanistyczne. Przedstawiają one pogłębioną analizę kulturowych uwarunkowań i przyczyn kryzysu ekologicznego, wypracowują nowy rodzaj relacji pomiędzy człowiekiem, kulturą a przyroda, dostarczają tak potrzebnych uzasadnień i motywacji dla działań przyjaznych środowisku, kształtują świadomość ekologiczną oraz kreują określone postawy i zachowania proekologiczne. To humanistyczny kierunek ochrony środowiska, określany także mianem humanizmu ekologicznego. Jego integralnym składnikiem są takie, nowo powstałe dyscypliny, jak: filozofia ekologiczna, etyka środowiskowa, ekoestetyka, psychologia ekologiczna, ekoteologia, ekopedagogika. Skrótową charakterystykę nurtu i konstytuujących go dyscyplin przedstawiamy w niniejszym artykule.

\section{Słowa kluczowe}

humanistyczny kierunek ochrony środowiska, ekofilozofia, etyka środowiskowa, ekoestetyka, psychologia ekologiczna, ekoteologia, ekopedagogika 


\section{Summary}

\section{Humanities for environment protection}

Humanities have important roles to play in actions aimed on preventing environmental degradation. They present the deep analysis of cultural determinants and conditions of ecological crisis, they elaborate a new dimension in relations between humans, culture and nature, they provide necessary justifications and motivations for environment - friendly actions, they build the ecological consciousness and create environmentally-oriented attitudes and activities. This humanistic dimension of the environment protection is often defined as the ecological humanism. Its integrate constituents are newly evolved disciplines, such as ecological philosophy, environmental ethics, eco-aesthetics, ecological psychology, eco-theology, eco-pedagogy. Here we present a concise characteristic of this field and the sub-disciplines comprised within this area of thinking.

\section{Keywords}

Humanistically-oriented environment protection, ecological philosophy, environmental ethics, eco-aesthetics, ecological psychology, eco-theology, eco-pedagogy 